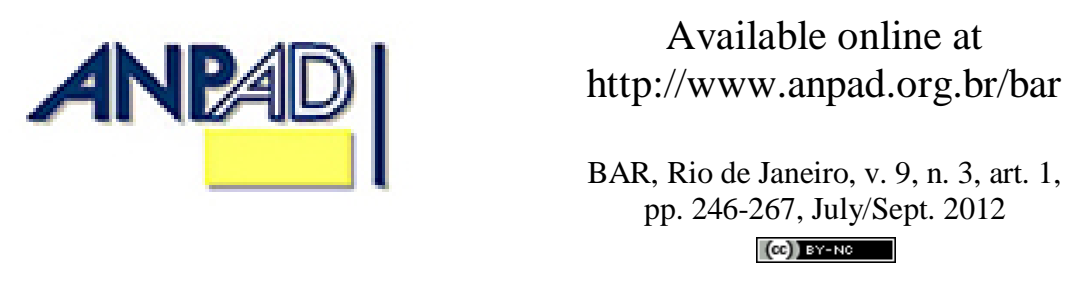

\title{
How Consumers Persuade Each Other: Rhetorical Strategies of Interpersonal Influence in Online Communities
}

\author{
Daiane Scaraboto * \\ E-mail address: dscaraboto@gmail.com \\ York University \\ Toronto, Canada. \\ Carlos Alberto Vargas Rossi \\ E-mail address: cavrossi@ea.ufrgs.br \\ Universidade Federal do Rio Grande do Sul - UFRGS \\ Porto Alegre, RS, Brazil. \\ Diego Costa \\ E-mail address: diegocostapinto@yahoo.com.br \\ Value and Persuasion Reseach Center, Reims Management School \\ Reims, France.
}

* Corresponding author: Daiane Scaraboto

York University - Keele Campus, 4700 Keele Street, Schulich School of Business, Office N304K, Toronto, ON, M3J 1P3, Canada.

Copyright (C 2012 Brazilian Administration Review. All rights reserved, including rights for translation. Parts of this work may be quoted without prior knowledge on the condition that the source is identified. 


\begin{abstract}
Persuasive messages are central to interpersonal influence in online communities, where consumers interact mainly through text. We employed a combination of netnography and computer-mediated discourse analysis to investigate how consumers exchange information related to products and brands in an online community. We identified a set of rhetorical strategies used by community members, including setting expectations, claiming expertise, prescribing, and celebrating acquiescence. Consumers employ these rhetorical strategies to influence each other's consumption decisions, report consumption decisions back to the community, and to gauge their influence on each other's choices. We compare this process to traditional types of interpersonal influence and discuss how our findings contribute to advancing the burgeoning literature on interpersonal influence in online contexts.
\end{abstract}

Key words: consumer decision; interpersonal influence; online communities. 


\section{Introduction}

As participation in online communities and social networks becomes increasingly popular (Valck, Bruggen, \& Wierenga, 2009), their relevance to the understanding of consumer behavior also grows (Dholakia, Bagozzi, \& Pearo, 2004; Kaplan \& Haenlein, 2010; Pitta \& Fowler, 2005). Online communities, particularly those associated with social networks, make it easier for consumers to chat about mutual interests, help one another with questions, voice complaints, share experiences and information about brands, and collaborate in the development of new products (Kozinets, Hemetsberger, \& Schau, 2008). These online platforms of interaction have affected several aspects of consumer behavior and associated managerial practices, including value creation (e.g. Schau, Muniz, \& Arnould, 2009), brand loyalty (Beaven \& Laws, 2007), and brand experience (Boulaire, Graf, \& Guelmani, 2008).

Observing consumers in their online activities, marketing researchers have recently started to investigate how interpersonal influence manifests online. Studies on electronic word-of-mouth (e.g. Andreassen \& Streukens, 2009; Kozinets, Valck, Wojnicki, \& Wilner, 2010; Ward \& Ostrom, 2006), online opinion leadership (e.g. Lyons \& Henderson, 2005; Senecal \& Nantel, 2004), as well as on the dynamics of online reference groups (Valck, 2005) have been conducted that start to shed light on these new forms of networked consumer influence. This recent but accumulating literature suggests that interpersonal influence in online contexts is very similar to offline interpersonal influence, despite happening on a scale never before contemplated (Gossieaux \& Moran, 2010). There is, however, one fundamental point of difference between interpersonal influence that unfolds in online communities and social networks and that which happens in offline contexts. In contrast to face-to-face relationships, interaction in online communities is mainly textual. These text-based conversations are usually stored on a community's website and become accessible to any registered member. These characteristics provide consumers - and researchers alike - with a track record of influential exchanges, particularly those which happen at one specific stage of the consumer decision process: the information search.

Past research has studied consumers' practices of information search and interpersonal influence mostly using surveys and experimental methods (e.g. Gilly, Graham, Wonfinbarger, \& Yale, 1998; Mourali, Laroche, \& Pons, 2005). Despite recent efforts to contextualize our knowledge of online interpersonal influence (e.g. Kozinets et al., 2010) we still lack a fully-developed and culturally informed theoretical perspective that illuminates the processes through which consumers influence each other online. In particular, we do not know much about the influence strategies that consumers use when cues about actual behaviour are limited and text is the main form of interaction. Therefore, our goals in this paper are to complement and extend prior research by addressing the following question: how do consumers exert, verify, and respond to interpersonal influence in online communities?

To gain insight into these issues, we investigated the interactions among participants of an online community dedicated to discussions of pregnancy, childbirth, and motherhood. This choice of community is justified in that consumption decisions related to motherhood, pregnancy, and childbirth tend to be high involvement ones (Vardeman \& Aldoory, 2008). In this context, consumers perceive high risk in making wrong choices and consequently extend the information search phase of the consumption decision process - where interpersonal influence most commonly happens (Peterson \& Merino, 2003).

Because most interactions in the investigated online community rely on text, we collected textual, qualitative data through netnography, and interpreted it with the aid of computer-mediated discourse analysis techniques (Herring, 2002) and rhetorical analysis (Zachry, 2009). While discourses encompass the universe of dialogic communication, rhetoric is the active, planned, effectual method by which persuasion is articulated. Hence, in any communication, one may choose to engage in rhetoric, but one always engages in discourse (Potter, 1996). 
Rhetorical analysis has proven useful in understanding persuasion in social politics (e.g. Fischer \& Forrester, 1993), social movements (e.g. Benford \& Snow, 2000), institutional change (e.g. Suddaby \& Greenwood, 2005), and business practices (e.g. Green, 2004; Norreklit, 2003). Notably, this approach has not yet been used to understand interpersonal influence among consumers. We believe that drawing on computer-mediated discourse analysis and rhetorical analysis for this purpose is valuable and addresses limitations of the perspectives thus far advanced to explain online interpersonal influence, which do not fully appreciate the textual nature of this phenomenon.

Considering the question we address and our deployment of netnography, computer-mediated discourse, and rhetorical analysis, our study's contributions are twofold. First, by looking at the naturally occurring interactions of consumers in online communities, we offer a counterpart to experimental studies and extend prior work that has taken an interpretive approach to interpersonal influence in consumer decision processes (e.g. Andrews \& Boyle, 2008; Kozinets et al., 2010; Valck, 2005). In doing so, we offer a culturally informed and unobtrusive interpretation of consumers' online interactions that integrates seemingly disparate approaches to the phenomena through its focus on persuasive texts. Second, this study extends our understanding of how interpersonal influence occurs in online contexts. By tracking online conversations, we identify the rhetorical strategies employed by consumers in online communities and offer initial insights on how influence unfolds through the messages consumers produce.

Our paper is organized as follows. We first present key elements of interpersonal influence theory that are relevant for understanding the dynamics of online consumer influence. We then describe our context and our methods. Our findings and our analysis are presented next, and we conclude with implications for theory and future research.

\section{Literature Review}

We briefly review the literature in online communities, the context in which we investigate online interpersonal influence, and revisit the concepts of reference groups and word-of-mouth in light of this context and in their relation to the information search stage of the consumer decision process.

\section{Online communities}

The notion of community has always been central to society; it is connected to the idea of a shared space, feelings of belonging, and the need for intimate inter-relationships. As pointed out by Bauman (2001), human beings present a desire to belong to a group with whom they can identify and share feelings, beliefs, and common interests.

Definitions of community emerged in the sociology literature at the beginning of the twentieth century, and a number of competing notions quickly followed, each of which emphasized place, common interests, or harmonious bonds as conditions for the development of these special groupings. In general, sociologists characterized community as a particular form of social organization based on small groups, for example neighborhoods, small towns, or geographically limited spaces (Delanty, 2003). Overall, most early definitions of community had geographical proximity as an integral component.

With the advent and dissemination of technologies enabling real-time communication over distance, the requisite of physical proximity has been reconsidered. Several scholars now suggest that communities may be established by factors other than shared locality; for example the perceived need for cooperation in order to achieve common goals (Baker \& Ward, 2002), the existence of shared symbols (Cohen, 1985), or a commonality of interests that transcend geographical boundaries, akin to a sense of spirit that cannot be defined by geography, environment, or activity (Pardy, 1994). 
There have been several attempts to define and categorize the numerous types of communities flourishing on the Internet. The definition of online communities as "social aggregations that emerge from the Internet when enough people carry on those public discussions long enough, with sufficient human feeling, to form webs of personal relationships in cyberspace" (Rheingold, 1993, p. 5) is considered one of the most relevant to describe and understand online groupings and is the one adopted in this research.

Relationships among individuals who participate in virtual communities vary enormously. Members may be offering or searching for advice, exchanging technical information and knowledge, or talking about events or other community members. All of these involve activities that transform virtual communities into emulations of a physical community, suggesting a close social and personal link between the online individual and his/her life outside the Internet (Fox, 2004).

Prior studies investigating interfaces between online communities and consumption have explored the role of online communities in value creation (e.g. Schau et al., 2009), the development of brand loyalty (Muniz \& Schau, 2005; Yim, Tse, \& Chan, 2008) and resistance practices (Kozinets \& Handelman, 2004) in online communities. Researchers have also identified some values and meanings attributed to consumption specific to online contexts (Porter, 2004). Although these studies represent a broad range of topics considering online communities and consumption, our goal is to investigate the process of interpersonal influence among consumers who interact over the Internet. Therefore, we will focus the remaining of this review on studies which have explored the impact consumers' participation in online communities has on their decision making.

\section{Interpersonal influence during information search}

Among studies that have investigated interpersonal influence in online contexts, two groups can be identified: those looking at the structure of online platforms as an enabler of interpersonal influence (e.g. Chu \& Kim, 2011; Riegner, 2007; Steffes \& Burgee, 2009), and those investigating the actual process of interpersonal influence as it happens online, usually employing interpretative methods (e.g. Andrews \& Boyle, 2008; Kozinets et al., 2010; Valck, 2005). We focus our attention on the latter, as their contexts and methodological approaches are closer to ours.

However, we limit our analysis of interpersonal influence to one phase of the consumer decision process: information search. Information search is one of the core phases of online consumer decisionmaking (Darley, Blankson, \& Luethge, 2010) and particularly so in high-involvement, high-risk consumption decisions (Beatty \& Smith, 1987). In our research context, most consumption decisions are characterized as high-involvement decisions into which future mothers conduct a lot of information search, because these decisions concern one's baby's health and well-being (Shapley, 2008). Consequently, pregnancy is understood as a risky period for novelty trials and experimentation, especially of new brands and alternative products (Lopes, 2005).

In this context, information search becomes even more relevant to consumption decisions. In fact, searching for trustworthy information is usually the first step taken by moms-to-be when facing a consumption decision that could eventually affect their babies. Consumers frequently search online for information that will aid in identifying a problem or need, facilitate comparisons between alternatives, and validate their choices (Beatty \& Smith, 1987). Currently, online information search is a common practice and the many characteristics and impacts of this practice on consumer decision-making have been investigated by marketing scholars (e.g. Grant, Clarke, \& Kryazis, 2007). We now turn to a brief review of the main studies addressing specific types of online interpersonal influence.

\section{Reference groups}

The concept of reference groups is a classical one in sociology. Reference groups are commonly defined as individuals or collectives that serve as a point of comparison (or reference) to a given individual in the constitution of its values, attitudes, or behaviors, thus influencing the individual's 
choices, behaviors, and attitudes (Shibutani, 1955). These groups have been classified as primary or secondary (Hyman, 1960). Primary groups (family, neighbors, and co-workers) are marked by members' concern for one another, shared activities and culture, and long periods of time spent together. Secondary groups (religious groups, associations, etc.) are marked by interactions that are less personal than those of the primary groups, and their relationships are temporary rather than longlasting.

Consumer behavior literature indicates that reference groups may alter consumers' choices in three different manners: through informational influence, normative acquiescence, and the influence on value expression (Bearden, Netemeyer, \& Teel, 1989; Wood, 2000). Informational influence occurs when consumers need an opinion or recommendation from members in the group to support a consumption decision. Normative acquiescence, also known as utilitarian influence, consists of a group's deliberate or implied pressure to conform to a certain standard. The influence on value expression is realized through the acceptance of a group's norms and values and the reproduction of its behaviors, aimed at obtaining a favorable response from other participants. Prior investigations suggest that the impact of the reference group is not equally important in all stages and types of decision-making. It is also expected that the relevance of reference groups' influence on consumer decisions vary across cultures and social groups (Bearden \& Etzel, 1982; Chattalas \& Harper, 2007; Childers \& Rao, 1992).

The Internet has fostered the formation of "specialized consumer knowledge reservoirs" in the form of online communities (Valck et al., 2009, p. 185). That means online communities frequently provide a repository of information produced by consumers about brands, companies, and products. Participants in these communities may not only exchange information as described above, but they may also develop friendly relationships based on their common interests and frequent interaction. In a multi-method study investigating how consumers use virtual communities as social and information networks in their decision-making processes, Valck, Bruggen, and Wierenga (2009) found that online communities "serve as reference groups that differ from traditional reference groups in their heterogeneous character" (p. 201), exposing participants to the most diverse opinions and behaviors. Ultimately, the authors explain, online communities represent "substantial social networks of consumer knowledge and companionship that affect consumer behavior" (p. 185). Along the same lines, additional research (Bickart \& Shindler, 2001; Constant, Sproull, \& Kielser, 1996) suggests that virtual communities may act as important reference groups for consumers that are at the same time different than, and similar to, traditional reference groups.

\section{Word-of-mouth}

Word-of-mouth (WOM) is a particular form of marketing communication that originates from consumers and is directed to other consumers (Dichter 1966). WOM is informal, usually oral, personal, and non-commercial (i.e. the speaker does not have a profit interest). The information transmitted through WOM most frequently refers to the possession, usage, or particular aspects, of goods, services, companies, and brands. Consumers are more likely to engage in WOM when they are committed, that is, when they "present higher identification with [a] company and hold feelings of attachment to maintaining valued relationships" (Matos \& Rossi, 2008, p. 581).

Similar to reference groups, word-of-mouth has also changed with the advent and dissemination of online platforms for communication. Consumer researchers have started to observe and investigate these changes. Kozinets, Valck, Wojnicki, and Wilner (2010), for example, tracked a marketing campaign that aimed to initiate online word-of-mouth for a new product. Focusing on the narrative strategies of bloggers who engaged in the dissemination of marketing messages through their blogs, the authors found that bloggers juggle promotional messages with the values they have developed for their blogs and their respective audiences. While this research adds much to our understanding of online WOM, it examines marketer initiated, not voluntary, mentions to brands and products which characterize most interpersonal influence (De Bruyn \& Lilien, 2008). In addition, blogs differ from online communities in an important way that affects how interpersonal influence unfolds in these 
environments: bloggers have an authority voice (L. K. Tan, Na, \& Theng, 2011), while in online communities authority is distributed among participants. Each blogger develops his or her own narrative style and chooses to address any topics s/he desires. Bloggers may also moderate comments from readers, or block them all together, maintaining a one-way form of communication with interested readers. In contrast to blogs, online communities are democratic and allow for all participants to create new topics, post replies, and discuss matters of their own interest. In online communities moderation is usually light-handed and conducted by participants who volunteer to observe and maintain a collegial environment. Because all, or at least most, participants have a voice in this context, interpersonal influence is more likely to unfold through conversations, being closer to what happens offline among reference groups, than to what has been described as word-of-mouth online.

\section{Research Method and Context}

In accordance with our research questions, and respecting the nature of the phenomenon, we adopted a qualitative research approach using netnography as a method. Netnography or online ethnography (Catterall \& Maclaran, 2002) was developed by Kozinets $(1998,2002,2009)$ as an adaptation of traditional ethnographic techniques to computer-mediated environments. In our study, we combine netnography to Computer-Mediated Discourse Analysis (for a detailed description, see Herring, 2002), an analytical framework which draws on linguistics, communication, and rhetoric studies to orient the analysis of computer-mediated communication.

Because interpersonal influence is one particular form of computer-mediated discourse characterized by persuasiveness, we are also sensitized to the principles of rhetorical analysis (Zachry 2009), which focuses on the agentic, planned, and effectual strategies of persuasion as they are articulated by individuals in spoken or written text. While we mostly followed the principles of computer-mediated discourse analysis, rhetorical analysis was helpful for the interpretation of the findings and the connection of findings with other relevant studies in the field.

Following the guidelines offered by Kozinets $(1999,2002,2009)$ for the use of netnography, and the ones outlined by Herring $(2002,2007)$ for the use of Computer-Mediated Discourse Analysis, our research developed in four stages: (1) defining the field, (2) entering the field, (3) collecting data, and (4) analyzing data.

In defining the research field, we limited our selection of online communities to those based on Orkut, the most popular online social network in Brazil. In 2006, 11 million of Orkut's more than 15 million users were registered as living in Brazil (Kugel, 2006). Five years later, in 2011, Orkut has 52 million Brazilian users, representing more than half of the total of registered accounts in the network (Aguiari, 2010). Other data indicates that approximately 73\% of Brazil's 66 million Internet users have active profiles on Orkut (Ecommerce, 2008). After a month of unobtrusive observation in diverse communities involving consumption decisions, one community named "Pregnancy, childbirth, and motherhood" was identified as the most suited to the development of this study. This online community fits all of the criteria suggested by Herring (2007) to differentiate between online communities and less structured gatherings on the Internet: (a) there is active and self-sustainable participation by a group of central participants; (b) there is sharing of stories, purposes, culture, norms, and values; (c) there is solidarity, support, and reciprocity; (d) there are conflicts and ways of solving conflicts; (e) there is group self-awareness; and (f) there are clear roles, hierarchies, rites, and control mechanisms.

The second stage in the research process, entrance in the field, involved the principal investigator's first contacts with the community and occurred after three months of non-participant observation in the selected community. After obtaining consent from the community owner, we created a topic on the community discussion board describing the research project and requesting the 
consent of all members to collect data and use the information from the community for academic purposes. Nine members replied to the post, all agreeing with the proposed research. The thread was kept on the forums during all of the data collection phase and no concerns or negative responses from community members were registered.

Data collection was initiated immediately after entering the field and ceased when the amount and variety of the data collected were considered sufficient to address our research question. Participant observation in the community was conducted by the first author during four months. However, the dataset also includes archival data collected since the creation of the community (October 2004) until September 2005. In this 12-month period, 601 threads were collected, comprising more than four thousand messages. Consistent with prior online research observations (e.g. Bernard, 2004; Elliott \& Jankel-Elliot, 2003; Kozinets, 2002) the amount of data collected on the online community was so vast that a qualitative analysis of the whole dataset proved extremely difficult to accomplish. Hence, a sample of the available data was selected for analysis (based on the sampling procedures suggested by Herring, 2007). This dataset consisted of 505 messages posted to the community discussion board. These messages were distributed in 53 discussion threads, initiated by 38 different participants.

While we recognize that not all participants contribute to online communities in the same way (see Kozinets, 1999 for a discussion of types of online community participants), we made a point of not limiting our sample to posts from frequent contributors, the devotees, because even less frequent contributors such as tourists and minglers, may occasionally attempt to exert influence through the use of rhetorical strategies.

Five years later, a second round of data collection was conducted in the same community in order to update the dataset and verify if any changes had occurred to the interactions unfolding in the community. The community had been continuously active since its inception, and in June 2011, the first author rejoined the group and scanned recent topics for discussions on brands, products, and purchase decisions. The community grew from approximately 5,000 to more than 29,000 members in the period of 2005-2011. In 2011, the number of discussions amounted to thousands of threads, and we observed that participants had devised mechanisms to help them navigate the sheer volume of information in their community. One of these community-created resources are fixed topics, and we decided to focus on these to update and complement our original dataset. Fixed topics are threads created by community moderators to keep the most relevant discussions on the front page of the discussion board. The longest fixed topic in Pregnancy, childbirth, and motherhood is named Community index - Useful Topics and contains links to other discussion threads considered highly relevant to participants. We updated our dataset by including all threads linked to this fixed topic.

Throughout the data collection process, the insights and observations made by all researchers were registered directly in the data files as preliminary analysis comments. We chose not to conduct interviews with community members to preserve as much as possible the non-intrusive character of the method. Finally, data analysis consisted of iterative readings of all of the posts included in the sample, aiming at identifying similarities and patterns in the participants' rhetorical manifestations. This dataset was manually and independently coded by each of the three authors, who then conferred, debated, and identified a set of conditions and practices that were pertinent to the research questions.

Content from the posters' profile pages was used as support data, helping in the contextualization of the posts analyzed. Member checks were conducted with five members of the community to capture their perspectives on our research findings and interpretation, and resulted in positive feedback. All names were exchanged for pseudonyms to preserve the online identities of participants. All messages quoted in the findings section were originally written in Portuguese and were translated by the authors. 


\section{Findings}

We observed that consumers create persuasive texts as they discuss brands, products, and consumption experiences in the online community investigated. We identified rhetorical strategies associated with four types of interpersonal influence, including setting expectations, prescribing, claiming expertise, and celebrating acquiescence. These types of text recurrently produced by participants are representative of the three forms of persuasive appeal described in classic rhetorical analysis: logos, that is, appeals to logic and focuses on the argument itself; ethos, which are appeals made on the basis of character of the speaker; and pathos, based on appeals to the audience's emotions (Amossy, 2005; Meyer, 1994). Table 1 details the three classical rhetorical types of persuasive appeals, which we explore in our discussion of the rhetorical strategies of interpersonal influence.

Table 1

\section{Rhetorical Strategies}

\begin{tabular}{|c|c|c|c|}
\hline & $\begin{array}{l}\text { Appeals to LOGOS } \\
\text { (logic, reasoning) }\end{array}$ & $\begin{array}{l}\text { Appeals to ETHOS } \\
\text { (character, ethics) }\end{array}$ & $\begin{array}{l}\text { Appeals to PATHOS } \\
\text { (emotion) }\end{array}$ \\
\hline Definition & $\begin{array}{l}\text { The argument itself; } \\
\text { the reasoning the author } \\
\text { uses; logical evidence }\end{array}$ & $\begin{array}{l}\text { How an author builds } \\
\text { credibility and } \\
\text { trustworthiness }\end{array}$ & $\begin{array}{l}\text { Words or passages an author } \\
\text { uses to activate emotions }\end{array}$ \\
\hline Form of Appeal & $\begin{array}{l}\text { Cites theories /scientific facts } \\
\text {. Indicates meanings or reasons } \\
\text {. Literal or historical analogies } \\
\text {. Offers definitions } \\
\text {. Cites factual data \& statistics } \\
\text {. Quotations } \\
\text {. Citations from experts } \\
\text {. Informed opinions } \\
\text {. Uses real life examples } \\
\text {. Tells personal anecdotes }\end{array}$ & $\begin{array}{l}\text { Author's } \\
\text { profession/background } \\
\text {. Appearing sincere, fair } \\
\text { minded, knowledgeable } \\
\text {. Conceding to opposition } \\
\text { where appropriate } \\
\text {. Morally/ethically likeable } \\
\text {. Use of appropriate } \\
\text { language for audience and } \\
\text { subject } \\
\text {. Appropriate vocabulary } \\
\text {. Correct grammar } \\
\text {. Professional format }\end{array}$ & $\begin{array}{l}\text { Emotionally loaded language } \\
\text { Vivid descriptions } \\
\text { Emotional examples } \\
\text { Anecdotes, testimonies, or } \\
\text { narratives about emotional } \\
\text { experiences or events } \\
\text { Figurative language } \\
\text { Emotional tone (humor, } \\
\text { sarcasm, disappointment, } \\
\text { excitement, etc.) }\end{array}$ \\
\hline $\begin{array}{l}\text { Effect on } \\
\text { Audience }\end{array}$ & $\begin{array}{l}\text { Evokes a cognitive, rational } \\
\text { response. Readers get a sense } \\
\text { of: "Oh, that makes sense" or } \\
\text { "Hmm, that really doesn't } \\
\text { prove anything." }\end{array}$ & $\begin{array}{l}\text { Helps readers to see the } \\
\text { author as reliable, } \\
\text { trustworthy, and credible. } \\
\text { The reader may respect the a } \\
\text { or his/her views. }\end{array}$ & $\begin{array}{l}\text { Evokes an emotional response. } \\
\text { Persuasion by emotion. } \\
\text { (usually evoking fear, } \\
\text { sympathy, empathy, anger) }\end{array}$ \\
\hline
\end{tabular}

Note. Adapted from Amossy, R. (2005). Da noção retórica de ethos à análise do discurso. Imagens de si no discurso: a construção do ethos. São Paulo: Editora Contexto; Meyer, M. (1994). Retórica e comunicação (9-16). Porto: Edições ASA.

\section{Setting Expectations}

In most threads posted on the community board, the first message is phrased as a question or a request for personal opinions about a specific product, brand, or service. In asking questions, participants usually refer to their lack of experience (e.g. "it's my first pregnancy"), setting 
expectations in relation to their need for information on the topic. Setting expectations is necessary because these questions frequently refer to issues that might seem obvious to more experienced mothers, such as the use of cosmetics or medications during pregnancy, unpleasant symptoms of pregnancy, or items that need to be purchased to ensure the baby's comfort. Participants appeal to logic as they justify their inaptitude to find the answers to questions that other members may consider naive (e.g. "I'll be a first time mom [therefore] I don't have any idea about..."). The message quoted below is the first one on a thread and illustrates this type of request.

"I'd like to know what moisturizers do u think are good to prevent stretch marks on the stomach, on the breasts. [...] I'll be a first time mom, so I'm wondering. [...] I don't have any idea about which moisturizer to buy, or how to take care of my body. [...]" (Marina, 10/27/2004).

The online environment makes it easier for consumers to receive trustworthy information from experienced moms or from women who are going through similar experiences. By bringing together people who are interested in and experienced on a certain topic, including experts such as doulas, doctors, and mothers of several children, this online community becomes a reliable source of information for its participants. Most importantly, the information obtained in an online community of consumers is deemed more reliable than information offered online by manufacturers and retailers (Bickart \& Schindler, 2001; Senecal \& Nantel, 2004).

Commonly, other participants will post additional requests for information and references which either extend the initial question or make it more specific. Another recurrent characteristic of messages in this type of post is the grouping of several questions into a single message. Many questions in a single message add a dramatic tone to the post, indicating the urgency in obtaining information and the overall lack of knowledge of the participant. Most of these messages are directed to the community as a whole and not to any particular member, which also sets expectations of receiving several relevant answers from a variety of community members.

The same rhetorical strategy is employed when participants reveal their concerns about making a wrong choice based on information obtained outside of the community. These participants post questions in order to verify the validity of the information obtained from external sources, as indicated in the following quote:

"My doctor suggested me socks with elastic compression. [...] I wonder if those are really good. [...] Kendall Socks?" (Michelly, 2/16/2005).

It is not possible, based solely on the data collected for this study, to verify the relevance of information obtained in the online community compared to other sources of information. However, our data offers evidence that when the request is for information that will be used to confirm or disconfirm information obtained from friends, doctors, and family members - people who are considered to be relevant sources of information for pregnant women (Lopes, 2005) - participants will set that expectation in their questions and search for the community's input and advice to compare with other sources of information.

\section{Claiming expertise}

To reduce the difficulties in evaluating a new brand or product, community members usually look for the opinion of those who have tried that brand or product before. Because community members are not, a priori, linked to marketers, it is expected that they will not have commercial interests and will base their recommendations only on prior experiences. In this sense, personal opinions and recommendations seem to be taken in this community as the most reliable evidence to support an informed choice, particularly by participants who are in their first pregnancy.

Nevertheless, participants in online communities have social goals - and being perceived as an influential member in the community can be one of these (Dholakia et al., 2004). We observed that, in answering questions posted to the community, members usually employ rhetorical devices to ascertain their expertise on a topic. For example, answers to requests for information usually offer more 
information than necessary to cover the initial question. Commonly, while recommending a moisturizer to be used during pregnancy, participants offer not only product names, but also prices, retailers where the product is available, product formula, usage tips, and compatible products. In the quotes below, for example, Maria Luísa offers information that allows participants to compare two different brands of moisturizers and concludes with a line similar to those commonly featured in advertisements: "You will feel your skin very silky". Similarly, Juliana draws on her experience as a salesperson and offers her pitch to a participant who posted a question about after-labor underwear:

"Look, I know two Mater Skin Creams (manufacturer COSMIATRIC 120G), THIS SELLS IN BIG PHARMACIES. Here in Rio I pay around 8 dollars. There is this other, which is Payot Maternité, this is more expensive, but it comes in $370 \mathrm{ml}$ or g. in big pharmacies 2. U'll feel your skin very silky!!! XOXO” (Maria Luísa, 10/27/2004).

\begin{abstract}
"The best are the postpartum panties high, dual front, from the LOVE SECRET code 82500, costs \$ 24.90 cotton inside is out micro fiber system is much good, and LIZ has the code 50230, it costs 35.90. They are great for the first few months. There is also a seamless modeling code of 70220 LIZ, that costs U.S. \$ 25.50 and it IS VERY GOOD AND DOES NOT APPEARS IN THE CLOTHES. these are the panties for postpartum I indicate that here in the shop and customers are very satisfied, when it comes to size, if you wear M buy a L, but look to the seller and ask for help. Basically high panties that go up to the belly button are good for the first months after labor" (Juliana, 3/1/2009).
\end{abstract}

When discussing diapers, a product that is very important for moms, and therefore very popular in this online community, participants make a point of mentioning their direct and indirect experiences with the product. Disposable diapers are one of the products that most future mothers will inevitably acquire during pregnancy or right after labor. Most women secure a reasonable stock of diapers before childbirth to avoid frequent trips to retailers after the baby is born and start to consume an average of 10 units a day; therefore even women who are in their first pregnancy can allege expertise on the topic. While some consumers will consider and purchase a wide range of diaper brands, most participants in this online community find choosing diaper brands a risky decision. These participants offer evidence that certain diapers may trigger severe allergies on babies' skin. Hence, they argue, the choice between brands has to be carefully made and not all brands should be considered. Several participants post accounts of their past experiences with different diaper brands, highlighting their investment in the choice.

The messages below, extracted from two different threads about diapers, illustrate the claims of expertise on this topic. Nina and other participants like her, who lack direct experience with the product, also frequently post their opinions on threads about brands and products. Their posts, however, are frequently mere descriptions of their decision process - uncertainties included - and usually refer to other sources of information, such as more experienced friends and family members.

"Early in the beginning of my pregnancy, a colleague told me that it's very usual for babies to have diaper allergies, and that Pampers is the one that gives fewer allergies. So I've bought them, I've chosen Pampers, so I'm safe. [...] now I will wait for Gabriel to be born, so, if he doesn't have any allergies I can buy other brands, not as expensive as Pampers" (Nina, 8/15/2005).

"Be careful with the cheapest brands, because the cheap can become expensive. So really, the best to do is to use known brands. I've done a lot of research and bought Pampers Basic. It's the most used by everyone I know, family, friends. [...]” (Amanda, 8/15/2005).

In contrast to Nina's approach, Amanda claims expertise on the matter and justifies her own choice of diaper brand as the best one by using expressions such as "I've done research" and "it's the most used by everyone I know". Even though she is not a mother yet, she claims to know what the best diaper brand is and her message has a prescriptive tone. Amanda's message also unveils other sources she uses to inform her consumption decisions: family and friends. In addition, by disowning other participants' intentions to buy cheaper brands, Amanda is reinforcing one of the pervasive values among participants: for the baby, only the best (Collett, 2005). 
Claims of expertise are also manifest in descriptions of the rigorous pursuit of the values underlying participants' consumption decisions during pregnancy and motherhood. In a study conducted to explore the relationship between motherhood, beauty, and the consumption of cosmetics, Lopes (2005) identified that the use of moisturizers, the practice of physical activities, and dietary changes are the main concerns of pregnant women in relation to their bodies. In the community we studied, topics related to diets, cosmetics, and exercising tended to generate agreement among participants, who considered these relevant matters and proceeded to exchange information and share experiences. The valorization of physical beauty and the intention to avoid allopathic medication stand out as prominent values among participants in the community, and manifestations of these values and preferences were observed across several posts. Although participants in this community largely differ in their social and demographical characteristics, these and other shared values allow them to concentrate on similarities and minimize conflict. The apparent agreement on how to deal with issues that could be controversial is partly achieved by the self-selective nature of participation in online communities, which allows for the development of strong norms of mutuality (Kavanaugh, Reese, Carroll, \& Rosson, 2005). In addition, when a participant exposes her values and creeds to the community, this mere exposure can influence the formation of communal values and impact other participants' personal values, thus leading them to be more similar to the collective average (Valck, 2005).

Issues related to these collective values were frequently raised in the community forums. The quotes below are examples of posts by participants who claim expertise based on the thorough adoption of the community values despite suffering, personal investment, or contradicting opinions:

"Look, Eduarda, I'm in week 29 and I use oil and moisturizer on my whole body almost every day, especially on my stomach, breasts and hips! And everything is smooth and pretty! [...] If it were truth that nothing helps, then were we to just let everything 'fall apart'?? Oh! No! We must take care of ourselves, yes" (Estela, 3/3/2005).

"Hi Girls! I'm in week 23 and I have soooo much heartburn! My doctor told me to take Mylanta .[...] But I think it's bad to take medication every day and sometimes I just bear the heartburn in order to avoid taking it every day and harming the baby[...]" (Pia, 6/29/2005).

\section{Prescribing}

Derived from the strategy of claiming expertise is another rhetorical form of interpersonal influence we call prescribing. The cordial tone that pervades debates and activities within the community we studied, combined with the open nature of the group, suggests that this is not an environment in which peer pressure is likely to flourish. In addition, it is also important to observe that in online communities, self-presentation is built through discourse, participation, and other cues (e.g. a participant's name and profile picture). Therefore, we assume that the evaluation of community members' prestige and status through consumption choices is less likely, given that these choices are made outside of the community boundaries.

Notwithstanding, peer pressure takes place in a very subtle way in the online community investigated. Some community members write their suggestions in form of prescriptions, seemingly assuming the role of a caring, nevertheless removed, expert in the topic. In the example quoted below, participants encourage one hesitant mother-to-be to adopt behaviors associated with the good pregnant woman or good mother (Gross \& Pattison, 2007), which is in accordance with the community values.

"Hi! Try to increase the amount of water that you drink little by little. Try also to drink natural juices. Lemon, for instance, is very light and it's also rich in vitamin C. It's practical, cheap and can be made fast, anywhere! It's a way to keep you hydrated and to hydrate the baby! I hope you are able to do this! XOXO, Lara" (Lara, 7/21/2005). 
In her post, Lara uses the imperative form Try to... Try also... and technical explanations that support her prescription (Lemon, for instance, is very light and also rich...) as health care practitioners frequently do (Gill, 1998).

In addition to this practice, it is also evident within the community that the values sustained by the community owner, who is a defender of humanized (i.e. natural) childbirth, are the default choice of most participants. When questions related to labor arise on the forums, peer pressure is more clearly present in the participants' messages and the general prescription is to follow the practices advocated by the community owner. The quote below (note once again the use of the imperative form, as in "don't forget..." and "run away from...") is an example of the answers received by a participant who asked for more information on how to choose an obstetrician:

"I agree with Lu and Patricia, but don't forget to question them also on childbirth, run away from the ones that are in favor of a caesarean. Kisses and the best of luck! Adri."(Adriana, 3/31/2005).

In the community investigated here, the recommendations and values postulated by participants differ from the mainstream values usually found in traditional reference groups. The owner and core participants in this community understand natural labor as an empowering choice to women and support the use of medical and technological intervention only when necessary. They do so in a country that has one of the highest rates of Caesarean sections in the world, mostly due to consumer demand (Hopkins, 2000). In the Brazilian public health network, the rate reaches 35\%, while in private hospitals, the rate approaches $80 \%$ (Freitas, Sakae, \& Jacomino, 2008). In this context, when participants conform to the values supported by the community, they also obtain support and motivation to position themselves against norms and values imposed by other groups of reference to whom they may relate. However, we note that peer pressure (normative influence) "can result in acceptance of group beliefs and behaviors, but it can also result in compliance with group norms without accepting all its beliefs and behaviors" (Valck, 2005, p. 37).

\section{Celebrating acquiescence}

When participants receive information and opinions that they consider useful, they usually post messages of gratitude to the community forums. In many occasions, participants re-open an old thread to post an update on the decisions they have made using information received in the community. This practice indicates participants' reciprocity to those who have helped them. Thankful messages also encourage the type of behavior explained in the social norms theory (Wiertz, Ruyter, \& Streukens, 2002), according to which expectations concerning the behavior of an individual are impinged by promises of rewards or by the threat of sanctions by the group or by the individual him/herself. According to Wiertz, Ruyter, and Streukens (2002), reciprocity norms are capable of explaining favorable social behaviors such as the ones we observed in this online community, including, for instance, the belief that people should help those who have helped them previously, or that something should always be offered in return for benefits received.

Manifestations of acquiescence and gratitude posted to the community forums not only indicate favorable behavior and the influence of social norms, but also suggest that participants consider the information obtained within the community as relevant in making their consumption decisions. The messages reproduced below illustrate this practice:

“Thanks! :) I've phoned the clinics for info. [...] I'm thinking of going once a week as well, at least in the beginning. Thanks, girls! Kisses to all of you!" (Susanna, 6/27/2005).

"Good to know that Matherskin is a good cream. I'm in the third month and I'm using it 2. [...] but as my belly is still too small, I couldn't tell if it was really good. I've liked the news!. Kisses! Oh, and I've heard that the one from Payot is very good, as this one" (Maura, 6/12/2005).

Given that actual consumption decisions are made outside of the online community boundaries, our dataset does not offer conclusive evidence that the information shared within the community affects the decision-making process. However, messages expressing gratitude, demonstrating the 
acceptance of information received, and suggesting reciprocity signal that the community input may indeed impact participants' attitudes toward brands and products, potentially exerting influence in their consumption decisions.

We observed that these messages are frequently followed by celebratory posts - where other participants congratulate a member for following the recommendations posted on the community. We call this rhetorical strategy celebrating acquiescence, for it reinforces, through the same mechanism explained above, the behavior of taking into account the information offered in the community, which may ultimately increase the impact of interpersonal influence in this context.

For example, after requesting advice on how to keep her hair blonde during pregnancy (dyes are not recommended because they contain chemicals that may be harmful to the fetus) and receiving several recommendations from community members to darken her hair using natural dyes, Jaqueline subsides and, giving up her blonde locks, posts a picture of herself with darker hair on her Orkut profile. Her decision to follow the recommendation of community members is celebrated, as the following post illustrates:

\footnotetext{
"Jaqueline your hair looks great! So your doctor gave you permission to change the color of your hair during pregnancy? I still think you shouldn't, because the chemicals are very strong, the smell is unbearable, and it's enough to burn your eyes. [...] This darker look is great on you.[...] Changing our looks really makes us feel better doesn't it? Big Hug. Cheers!” (Fernanda, 7/26/06).
}

Note, however, that Fernanda still questions the decision made by Jaqueline, asking if she got her doctors' approval. Prioritizing looks over health would be against the communal values, so Fernanda makes a point of ensuring that the advice given in the community is taken seriously and checked against other sources of information.

\section{Discussion}

This research aimed to investigate how consumers try to influence each other while exchanging information related to products and brands in an online community. Our research suggests the following dynamic: initially, a consumer asks for information about a brand or product, requests help or advice, or poses a general question to the community. When doing so, most consumers explore rhetorical modes in their questions aiming to maximize the number or the quality of responses. We found that these requests may be framed as emotional appeals (pathos), be based on claims of lack of expertise (in a reversed-type appeal to ethos), or present contradictory information, posing a dilemma to be solved by the community (logos). We grouped these strategies into an overall category called setting expectations, for they anticipate how the process of interpersonal influence will unfold within the group, for that particular topic. Therefore, our first insight is that consumers deliberately seek to amplify their exposure to interpersonal influence by composing persuasive requests for information and posting these to online communities of interest.

In the sequence, other participants follow up to a request with answers, comments, or soliciting clarification. A second round, or multiple rounds, of questions and answers may follow, as the participant who originally posed the question asks for clarification and other participants join the discussion to reinforce the need for information on a topic or to extend that need to related topics.

Inquiring participants are not the only ones who employ rhetorical strategies in their information choice. Those who provide answers, advice, and suggestions also employ rhetorical strategies to better frame their contributions as relevant, useful, and worth consideration. They do so by claiming expertise on a topic (ethos), prescribing and recommending based on evidence, citing external sources of information and other credible support (logos), or appealing to the emotions of other participants (pathos). In fact, emotional appeals pervade most forms of text found in the community. Therefore, while cognizant of this particular rhetorical mode, we did not consider it as a separate category. 
Finally, participants who benefited from the information and advice shared in the community frequently revisit a topic to either thank others for their comments or to report back on the consumption decision made. Similarly, those offering information and advice usually revisit the topic for closure, either corroborating or questioning the decisions made by consumers who report their choices. When the course of action reported by a participant is in alignment with the core values of the community, that course of action is celebrated and raised to the status of an exemplar experience. We note, however, that due to the lack of evidence of actual behavior, it is not possible for participants to fully ascertain that their attempts at influence have been successful. Once again it is the use of rhetorical strategies that help participants to gauge the accuracy of reported behavior and to respond accordingly.

In sum, we identified a set of rhetorical strategies used by community members, including setting expectations, claiming expertise, prescribing, and celebrating acquiescence. These rhetorical strategies, particular to discussions of products, brands, and consumption decisions in online communities, extend the applicability of traditional modes of rhetorical persuasion to the study of interpersonal influence among consumers. Through the use of persuasive modes of text, participants in the community we investigated influence each other's consumption decisions, report consumption decisions back to the community, and gauge their influence on each other's choices. Table 2 summarizes these strategies.

Table 2

Rhetorical Strategies of Interpersonal Influence

\begin{tabular}{llll}
\hline \multicolumn{1}{c}{$\begin{array}{c}\text { Setting } \\
\text { Expectations }\end{array}$} & \multicolumn{1}{c}{ Prescribing } & \multicolumn{1}{c}{$\begin{array}{c}\text { Claiming } \\
\text { Expertise }\end{array}$} & $\begin{array}{c}\text { Celebrating } \\
\text { Aquiescence }\end{array}$ \\
\hline LOGOS & $\begin{array}{l}\text { Posing a dilemma to } \\
\text { be solved by the } \\
\text { community }\end{array}$ & $\begin{array}{l}\text { Prescribing and } \\
\text { recommending based on } \\
\text { evidence, external sources } \\
\text { of information, and other } \\
\text { credible support. }\end{array}$ & - \\
\hline ETHOS & $\begin{array}{l}\text { Lack of expertise } \\
\text { (reversed appeal to } \\
\text { ethos })\end{array}$ & - & $\begin{array}{l}\text { Claiming Expertise } \\
\text { on the topic }\end{array}$ \\
\hline
\end{tabular}

$\begin{array}{llll}\text { PATHOS } & \begin{array}{l}\text { Framing requests as } \\ \text { emotional appeals }\end{array} & \begin{array}{l}\text { Appealing to community } \\ \text { values }\end{array} & -\end{array} \begin{aligned} & \begin{array}{l}\text { Appealing to the } \\ \text { emotions of other } \\ \text { participants }\end{array}\end{aligned}$

Note. Source: Authors.

An important contribution of this study has been, therefore, to question the common understanding of interpersonal influence as a neutral (i.e. disinterested) source of information for consumers, frequently preferable to that offered by marketers, who have vested interests in offering advice that promotes their products. When information search happens in online communities of interest, such as the one investigated in this study, participant's social goals (e.g. to achieve reputation or gain prestige) and their willingness to promote and sustain communal values may lead them to exert interpersonal influence that is biased. Some ways in which this bias is manifested is through the overestimation of the validity of the information provided, the overextension of personal expertise to unrelated topics, or through appeals to emotions when rational arguments could prove sufficient.

In comparing the process described here to traditional types of interpersonal influence it is important to note that one essential difference between traditional reference groups and online communities is the diversity of participants. Online communities bring together individuals from 
various social and demographic backgrounds who share interests related to the community topic. In the community we examined in this study, the participants congregated around the topics of pregnancy, labor, and motherhood. In online communities, pregnant women find support and advice no matter where they are located, and at any given point in time.

The interactions among participants in the community we investigated are very similar to those of individuals belonging to offline groups. Because we did not interview participants on their online activities, we cannot determine the frequency of their visits to the community forums. However, topics with dozens of messages succeeding one another within the same day indicate a high frequency of member participation and the taking of turns (to post messages), as in a face-to-face conversation. Our analysis of the post listings since the creation of the community as well as of recent posts also suggest that a number of the community core members, apart from being frequent posters, are also long-term participants who are active on the forums for several years in a row. Therefore, we suggest that this online community could be considered a primary reference group, at least for this selected group of members who participate daily and for extended periods of time.

It is also important to observe that the majority of the topics included in our sample were initiated by women who were in their first pregnancy. The answers to their inquietudes and requests were usually posted by women with prior experience on motherhood, suggesting an informal hierarchical classification of group members similar to the one that occurs in traditional reference groups (Dawson \& Chatman, 2001). These findings suggest that marketers should aim to facilitate interactions between experienced and novice consumers in online communities, keeping in mind that, as suggested in prior research, reference group appeal is the preferred risk reduction mechanism for consumers who have to make online consumption decisions (S. J. Tan, 1999). Another possibility to capitalize on these characteristics of reference groups is to attempt to associate participation in online communities with established practices of consumer hierarchy (e.g. rewards and loyalty programs).

Word-of-mouth also is a common aspect of interpersonal influence in the community we investigated. Participants frequently cite brands and products, associating their experience with these with a recommendation. Different types of decision-making processes were identified within the online community, and participants seem to take each other's opinions and information into account with the same openness for relatively simple decisions, such as the choice of a moisturizer, as they employ in complex decisions, such as the choice of a hospital for childbirth. In this case, the traditional classification of consumption decisions in low and high involvement types is blurred by cultural and social expectations of ideal practices during pregnancy and motherhood. This context becomes one where all decisions are perceived by its members as high-risk, high-involvement ones.

\section{Theoretical and managerial implications}

Our findings support prior studies (Bickart \& Schindler, 2001; Burnett, 2000; Kozinets et al., 2010; Valck, 2005) in highlighting the importance consumers attribute to information and knowledge gained in online communities. The implications of this investigation are not restrained to any specific brand or product category. The findings presented here can inspire researchers and managers alike to understand similar phenomena related to other product categories, brands, or services and activities, purchased either online or offline.

We advanced prior research in identifying specific rhetorical strategies employed by consumers as they exchange information about products and brands in online communities. We associated these strategies to traditional modes of persuasion developed in rhetorical studies and to offline modes of interpersonal influence. This knowledge may help marketing scholars and practitioners to identify communication forms that are more persuasive to a specific audience of consumers; the particular needs of a small consumer group in terms of information; and to understand what arguments work better with consumers who are searching for information to make high-risk, high-involvement decisions. The identification and application of rhetorical strategies of interpersonal influence works better in online communities, where all naturally occurring conversations among consumers are 
automatically archived and can be accessed by other participants anytime they need information. Similarly, online communities allow researchers to observe, in a non-obtrusive manner, word-ofmouth and reference group dynamics among consumers, a phenomenon hardly observable in natural offline environments.

\section{Limitations and future research}

One of the limitations of such a study is the inability to generalize the obtained results; because, among millions of active virtual communities on the Internet, this study is based on evaluation of participants' interaction in only one community. Surveys, interviews, and systematic observation of multiple online communities could be used to complement and extend our findings.

It is also relevant to consider, when evaluating the results of this study, that some restrictions might have been imposed by the predominance of women in the researched community. In the evaluation of the results of their research on on-line forums, Bickart and Schindler (2001) discovered the possibility that women were more inclined to experience the effects of participating in Internet forums than men, therefore presenting a greater tendency to be influenced by other participants.

Future studies should examine the role of rhetorical strategies of interpersonal influence in other contexts. Parallel studies on different types of virtual communities are also a venue for future discoveries, such as specific brand communities (Cova \& Carrére, 2002; McWilliam, 2000), general interest communities, communities created by members, communities sponsored by organizations (Porter, 2004), and communities that use different virtual environments, such as chats, virtual worlds, forums, and discussion lists (Kozinets, 1999), in order to identify factors that influence the development and nature of the relationships among participants in the same community.

\section{Received 25 November 2010; received in revised form 29 September 2011.}

\section{References}

Aguiari, V. (2010, August 25). Orkut é 8 vezes maior que Facebook no Brasil. Info. Retrieved August 25, 2010, from http://info.abril.com.br/noticias/internet/orkut-e-8-vezes-maior-que-facebookno-brasil-25082010-6.shl

Amossy, R. (2005). Da noção retórica de ethos à análise do discurso. Imagens de si no discurso: a construção do ethos. São Paulo: Editora Contexto.

Andreassen, T. W., \& Streukens, S. (2009). Service innovation and electronic word-of-mouth: is it worth listening to? Managing Service Quality, 19(3), 249-265. doi: $10.1108 / 09604520910955294$

Andrews, L., \& Boyle, M. V. (2008). Consumers' accounts of perceived risk online and the influence of communication sources. Qualitative Market Research: an International Journal, 11(1), 5975. doi: 10.1108/13522750810845559

Baker, P., \& Ward, A. (2002). Bridging temporal and spatial 'gaps': the role of information and communication technologies in defining communities. Information, Communication \& Society, 5(2), 207-224. doi: 10.1080/13691180210130789

Bauman, Z. (2001). Modernidade líquida (P. Dentzien, Trans.). Rio de Janeiro: Jorge Zahar. (Original work published 2000).

Bearden, W., \& Etzel, M. (1982). Reference group influence on product and brand purchase decisions. Journal of Consumer Research, 9(2), 183-194. doi: 10.1086/208911 
Bearden, W., Netemeyer, R., \& Teel, J. (1989). Measurement of consumer susceptibility to interpersonal influence. Journal of Consumer Research, 15(4), 473-481. doi: 10.1086/209186

Beatty, S. E., \& Smith, S. M. (1987). External search effort: an investigation across several product categories. Journal of Consumer Research, 14(1), 83-95. doi: 10.1086/209095

Beaven, Z., \& Laws, C. (2007). 'Never let me down again': loyal customer attitudes towards ticket distribution channels for live music events: a netnographic exploration of the US leg of the Depeche Mode 2005-2006 World Tour. Managing Leisure, 12(2-3), 120-142. doi: $10.1080 / 13606710701339322$

Benford, R. D., \& Snow, D. A. (2000). Framing processes and social movements: an overview and assessment. Annual Review of Sociology, 26(1), 611-639. doi: 10.1146/annurev.soc.26.1.611

Bernard, Y. (2004). La netnographie: une nouvelle méthode d'enquête qualitative basée sur les communautés virtuelles de consommation. Décisions Marketing, (36), 49-62.

Bickart, B., \& Schindler, R. (2001). Internet forums as influential sources of consumer information. Journal of Interactive Marketing, 15(3), 31-40. doi: 10.1002/dir.1014

Boulaire, C., Graf, R., \& Guelmani, R. (2008). Online communities serving the consumer/producer: observations from the study of a fantasy world. Direct Marketing: an International Journal, 2(4), 199-220. doi: 10.1108/17505930810931017

Burnett, G. (2000). Information exchange in virtual communities: a typology. Information Research, 5(4), 1-25. Retrieved October 5, 2010, from http://informationr.net/ir/5-4/paper82.html

Catterall, M., \& Maclaran, P. (2002). Researching consumers in virtual worlds: a cyberspace odyssey. Journal of Consumer Behaviour, 1(3), 228-237. doi: 10.1002/cb.68

Chattalas, M., \& Harper, H. (2007). Navigating a hybrid cultural identity: Hispanic teenagers' fashion consumption influences. Journal of Consumer Marketing, 24(6), 351-157. doi: $10.1108 / 07363760710822936$

Childers, T., \& Rao, A. (1992). The influence of familial and peer-based reference groups on consumer decisions. Journal of Consumer Research, 19(2), 198-211. doi: 10.1086/209296

Chu, S., \& Kim, Y. (2011). Determinants of consumer engagement in electronic word-of-mouth (eWOM) in social networking sites. International Journal of Advertising, 30(1), 47-75. doi: 10.2501/IJA-30-1-047-075

Cohen, A. P. (1985). The symbolic construction of community. London: Routledge.

Collett, J. (2005). What kind of mother am I? Impression management and the social construction of motherhood. Symbolic Interaction, 28(3), 327-347. doi: 10.1525/si.2005.28.3.327

Constant, D., Sproull, L., \& Kiesler, S. (1996). The kindness of strangers: the usefulness of electronic weak ties for technical advice. Organization Science, 7(2), 119-135. doi: 10.1287/orsc.7.2.119

Cova, B., \& Carrére, V. (2002). Les communautés de passionés de marque: opportunité ou menace sur le net? [The communities of brand fans: opportunity or threat on the net] Revue Française du Marketing, 189/190, 119-130.

Darley, W., Blankson, C., \& Luethge, D. (2010). Toward an integrated framework for online consumer behavior and decision making process: a review. Psychology and Marketing, 27(2), 94-116. doi: 10.1002/mar 
Dawson, E., \& Chatman, E. (2001). Reference group theory with implications for information studies: a theoretical essay. Information Research, 6(3), 6-3.

De Bruyn, A., \& Lilien, G. L. (2008). A multi-stage model of word-of-mouth influence through viral marketing. International Journal of Research in Marketing, 25(3), 151-163. doi: 10.1016/j.ijresmar.2008.03.004

Delanty, G. (2003). The making of a post-western Europe: a civilizational analys. Thesis Eleven, 72(1), 8-25. doi: 10.1177/0725513603072001002

Dholakia, U., Bagozzi, R., \& Pearo, L. (2004). A social influence model of consumer participation in network-and small-group-based virtual communities. International Journal of Research in Marketing, 21(3), 241-263. doi: 10.1016/j.ijresmar.2003.12.004

Dichter, E. (1966). How word-of-mouth advertising works. Harvard Business Review, 44(6), 147-166.

Ecommerce. (2008). Datafolha: 64,5 milhões de internautas no Brasil. Retrieved October 5, 2010, from http://www.ecommerce.tv.br/datafolha-64-5-milhoes-de-internautas-no-brasil

Elliott, R. N., \& Jankel-Elliot, N. (2003). Using ethnography in strategic consumer research. Qualitative Market Research: an International Journal, 6(4), 215-223. doi: $10.1108 / 13522750310495300$

Fischer, F., \& Forester, J. (1993). The argumentative turn in policy analysis and planning. Durham, NC: Taylor \& Francis.

Fox, S. (2004). The new imagined community: identifying and exploring a bidirectional continuum integrating virtual and physical communities through the community embodiment model (CEM). Journal of Communication Inquiry, 28(1), 47-62. doi: 10.1177/0196859903258315

Freitas, P., Sakae, T., \& Jacomino, M. (2008). Medical and non-medical factors associated with cesarean section rates in a university hospital in southern Brazil. Cadernos de Saúde Pública, 24(5), 1051-1061. doi: 10.1590/S0102-311X2008000500012

Gill, V. T. (1998). Doing attributions in medical interaction: patients' explanations for illness and doctors' responses. Social Psychology Quarterly, 61(4), 342-360. doi: 10.2307/2787034

Gilly, M. C., Graham, J. L., Wolfinbarger, M. F., \& Yale, L. J. (1998). A dyadic study of interpersonal information search. Journal of the Academy of Marketing Science, 26(2), 83-100. doi: $10.1177 / 0092070398262001$

Gossieaux, F., \& Moran, E. K. (2010). The hyper-social organization: eclipse your competition by leveraging social media. New York: McGraw-Hill.

Grant, G., Clarke, R., \& Kryiazis, E. (2007). A review of factors affecting online consumer search behaviour from an information value perspective. Journal of Marketing Management, 23(5-6), 519-533. doi: 10.1362/026725707X212801

Green, S. E., Jr. (2004). A rhetorical theory of diffusion. The Academy of Management Review, 29(4), 653-669. doi: 10.2307/20159076

Gross, H., \& Pattison, H. (2007). Sanctioning pregnancy: a psychological perspective on the paradoxes and culture of research. London: Routledge.

Herring, S. (2002). Computer-mediated communication on the internet. Annual Review of Information Science and Technology, 36(1), 109-168. doi: 10.1002/aris.1440360104 
Herring, S. (2007). A faceted classification scheme for computer-mediated discourse. Language@ Internet, 4(1), 1-37.

Hopkins, K. (2000). Are Brazilian women really choosing to deliver by cesarean? Social Science \& Medicine, 51(5), 725-740. doi: 10.1016/S0277-9536(99)00480-3

Hyman, H. H. (1960). Reflections on reference groups. Public Opinion Quarterly, 24(3), 383-396. doi: $10.1086 / 266959$

Kaplan, A. M., \& Haenlein, M. (2010). Users of the world, unite! The challenges and opportunities of social media. Business Horizons, 53(1), 59-68. doi: 10.1016/j.bushor.2009.09.003

Kavanaugh, A., Reese, D., Carroll, J., \& Rosson, M. (2005). Weak ties in networked communities. The Information Society, 21(2), 119-131. doi: 10.1080/01972240590925320

Kozinets, R. (1998). On netnography: initial reflections on consumer research investigations of cyberculture. Advances in Consumer Research, 25(1), 366-371.

Kozinets, R. (1999). E-tribalized marketing? The strategic implications of virtual communities of consumption. European Management Journal, 17(3), 252-264. doi: 10.1016/S02632373(99)00004-3

Kozinets, R. (2002). The field behind the screen: using netnography for marketing research in online communities. Journal of Marketing Research, 39(1), 61-72. doi: 10.1509/jmkr.39.1.61.18935

Kozinets, R. (2009). Netnography: doing ethnographic research online. Thousand Oaks, CA: Sage Publications Ltd.

Kozinets, R., \& Handelman, J. (2004). Adversaries of consumption: consumer movements, activism, and ideology. Journal of Consumer Research, 31(3), 691-704. doi: 10.1086/425104

Kozinets, R., Hemetsberger, A., \& Schau, H. J. (2008). The wisdom of consumer crowds: collective innovation in the age of networked marketing. Journal of Macromarketing, 28(4), 339-354. doi: $10.1177 / 0276146708325382$

Kozinets, R., Valck, K. de, Wojnicki, A., \& Wilner, S. (2010). Networked narratives: understanding word-of-mouth marketing in online communities. Journal of Marketing, 74(2), 71-89. doi: 10.1509/jmkg.74.2.71

Kugel, S. (2006, April 10). A web site born in U.S. finds fans in Brazil. The New York Times, Technology, 2. Retrieved October 5, 2010, from http://www.nytimes.com/2006/04/10/technology/10orkut.html

Lopes, M. (2005). O conceito de beleza e maternidade: um estudo exploratório do comportamento feminino (Master's thesis). Universidade Federal do Rio de Janeiro, Rio de Janeiro, RJ, Brazil.

Lyons, B., \& Henderson, K. (2005). Opinion leadership in a computer-mediated environment. Journal of Consumer Behaviour, 4(5), 319-329. doi: 10.1002/cb.22

Matos, C. A., \& Rossi, C. A. V. (2008). Word-of-mouth communications in marketing: a metaanalytic review of the antecedents and moderators. Journal of the Academy of Marketing Science, 36(4), 578-596. doi 10.1007/s11747-008-0121-1

McWilliam, G. (2000). Building stronger brands through online communities. Sloan Management Review, 41(3), 43-54.

Meyer, M. (1994). Retórica e comunicação. Porto: Edições ASA. 
Mourali, M., Laroche, M., \& Pons, F. (2005). Antecedents of consumer relative preference for interpersonal information sources in pre-purchase search. Journal of Consumer Behaviour, 4(5), 307-318. doi: 10.1002/cb.16

Muniz, A. M., Jr., \& Schau H. J. (2005). Religiosity in the abandoned Apple Newton brand community. Journal of Consumer Research, 31(4), 737-747. doi: 10.1086/426607

Norreklit, H. (2003). The balanced scorecard: what is the score? A rhetorical analysis of the balanced scorecard. Organizations \& Society, 28(6), 591-619. doi: 10.1016/S0361-3682(02)00097-1

Pardy, B. (1994). Recreating community - new perspectives, new directions. Nova Scotia: Saint Mary's University.

Peterson, R. A., \& Merino, M. C. (2003). Consumer information search behavior and the internet. Psychology and Marketing, 20(2), 99-121. doi: 10.1002/mar.10062

Pitta, D. A., \& Fowler, D. (2005). Internet community forums: an untapped resource for consumer marketers. Journal of Consumer Marketing, 22(5), 265-274. doi: 10.1108/07363760510611699

Porter, C. (2004). A typology of virtual communities: a multi-disciplinary foundation for future research. Journal of Computer-Mediated Communication, 10(1). doi: 10.1111/j.10836101.2004.tb00228.x

Potter, J. (1996). Representing reality: discourse, rhetoric and social construction. London, UK: Sage Publications Inc.

Rheingold, H. (1993). The virtual community: homesteading on the electronic frontier. Reading, MA: Addison-Wesley.

Riegner, C. (2007). Word of mouth on the web: the impact of web 2.0 on consumer purchase decisions. Journal of Advertising Research, 47(4), 436-437. doi: 10.2501/S0021849907070456

Schau, H. J., Muñiz, A., Jr., \& Arnould, E. (2009). How brand community practices create value. Journal of Marketing, 73(5), 30-51.

Senecal, S., \& Nantel, J. (2004). The influence of online product recommendations on consumers online choices. Journal of Retailing, 80(2), 159-169. doi: 10.1016/j.jretai.2004.04.001

Shapley, D. (2008). Pregnant? Reconsider using those cosmetics. The Daily Green. Retrieved July 15, 2010, from http://www.thedailygreen.com/environmental-news/latest/beauty-products47120106\#ixzz0z37FSPbC

Shibutani, T. (1955). Reference groups as perspectives. American Journal of Sociology, 60(6), 562569.

Steffes, E. M., \& Burgee, L. E. (2009). Social ties and online word of mouth. Internet Research, 19(1), 42-59. doi: 10.1108/10662240910927812

Suddaby, R., \& Greenwood, R. (2005). Rhetorical strategies of legitimacy. Administrative Science Quarterly, 50(1), 35-67. doi: 10.1017/S1049096505050134

Tan, L. K., Na, J., \& Theng, Y. (2011). Influence detection between blog posts through blog features, content analysis, and community identity. Online Information Review, 35(3), 425-442. doi: $10.1108 / 14684521111151450$

Tan, S. J. (1999). Strategies for reducing consumers' risk aversion in online shopping. Journal of Consumer Marketing, 16(2), 163-180. doi: 10.1108/07363769910260515

Valck, K. de (2005). Virtual communities of consumption: networks of consumer knowledge and 
companionship. (Doctoral Disseration) Erasmus University Rotterdam, Rotterdam, Netherlands.

Valck, K. de, Bruggen, G. van, \& Wierenga, B. (2009). Virtual communities: a marketing perspective. Decision Support Systems, 47(3), 185-203. doi: 10.1016/j.dss.2009.02.008

Vardeman, J. E., \& Aldoory, L. (2008). A qualitative study of how women make meaning of contradictory media messages about the risks of eating fish. Health Communication, 23(3), 282291. doi: $10.1080 / 10410230802056396$

Ward, J. C., \& Ostrom, A. L. (2006). Complaining to the masses: the role of protest framing in customer-created complaint web sites. Journal of Consumer Research, 33(2), 220-230. doi: $10.1086 / 506303$

Wiertz, C., Ruyter, K. de, \& Streukens, S. (2002, May). Virtual communities for service delivery: transferring the notion of pro-social behavior from 'place' to 'space'. Proceedings of the European Marketing Academy Conference, Braga, Portugal, 31.

Wood, W. (2000). Attitude change: persuasion and social influence. Annual Review of Psychology, 51, 539-570. doi: 10.1146/annurev.psych.51.1.539

Yim, C., Tse, D., \& Chan, K. (2008). Strengthening customer loyalty through intimacy and passion: roles of customer-firm affection and customer-staff relationships in services. Journal of Marketing Research, 45(6), 741-756. doi: 10.1509/jmkr.45.6.741

Zachry, M. (2009). Rhetorical analysis and professional communication. In F. Bargiela-Chippini (Ed.), The handbook of business discourse (pp. 68-79). Edinburgh, UK: Edinburgh University Press. 